\title{
Article \\ Performance of the Polydopamine-Graphene Oxide Composite Substrate in the Osteogenic Differentiation of Mouse Embryonic Stem Cells
}

\author{
Na Young Shim and Jung Sun Heo* \\ Department of Maxillofacial Biomedical Engineering and Institute of Oral Biology, School of Dentistry, \\ Kyung Hee University, 26 Kyunghee-daero, Dongdaemun-gu, Seoul 02447, Korea; sny4845@hanmail.net \\ * Correspondence: heojs@khu.ac.kr; Tel.: +82-2-961-0470
}

Citation: Shim, N.Y.; Heo, J.S. Performance of the

Polydopamine-Graphene Oxide Composite Substrate in the Osteogenic Differentiation of Mouse Embryonic Stem Cells. Int. J. Mol. Sci. 2021, 22, 7323. https://doi.org/ $10.3390 /$ ijms 22147323

Academic Editor: Francesca Paino

Received: 25 May 2021

Accepted: 5 July 2021

Published: 7 July 2021

Publisher's Note: MDPI stays neutral with regard to jurisdictional claims in published maps and institutional affiliations.

Copyright: (c) 2021 by the authors. Licensee MDPI, Basel, Switzerland. This article is an open access article distributed under the terms and conditions of the Creative Commons Attribution (CC BY) license (https:// creativecommons.org/licenses/by/ $4.0 /)$.
Abstract: Graphene oxide (GO) is a biocompatible material considered a favorable stem cell culture substrate. In this study, GO was modified with polydopamine (PDA) to facilitate depositing GO onto a tissue culture polystyrene (PT) surface, and the osteogenic performance of the PDA/GO composite in pluripotent embryonic stem cells (ESCs) was investigated. The surface chemistry of the PDA/GO-coated PT surface was analyzed by scanning electron microscopy (SEM) and X-ray photoelectron spectroscopy (XPS). A high cell viability of ESCs cultured on the PDA/GO compositecoated surface was initially ensured. Then, the osteogenic differentiation of the ESCs in response to the PDA/GO substrate was assessed by alkaline phosphatase (ALP) activity, intracellular calcium levels, matrix mineralization assay, and evaluation of the mRNA and protein levels of osteogenic factors. The culture of ESCs on the PDA/GO substrate presented higher osteogenic potency than that on the uncoated control surface. ESCs cultured on the PDA/GO substrate expressed significantly higher levels of integrin $\alpha 5$ and $\beta 1$, as well as bone morphogenetic protein receptor (BMPR) types I and II, compared with the control groups. The phosphorylation of extracellular signal-regulated kinase (ERK)1/2, p38, and c-Jun-N-terminal kinase (JNK) mitogen-activated protein kinases (MAPKs) was observed in ESCs culture on the PDA/GO substrate. Moreover, BMP signal transduction by SMAD1/5/8 phosphorylation was increased more in cells on PDA/GO than in the control. The nuclear translocation of SMAD1/5/8 in cells was also processed in response to the PDA/GO substrate. Blocking activation of the integrin $\alpha 5 / \beta 1$, MAPK, or SMAD signaling pathways downregulated the PDA/GO-induced osteogenic differentiation of ESCs. These results suggest that the PDA/GO composite stimulates the osteogenic differentiation of ESCs via the integrin $\alpha 5 / \beta 1$, MAPK, and BMPR/SMAD signaling pathways.

Keywords: mouse embryonic stem cells; graphene oxide; polydopamine; osteogenic differentiation; integrins; bone morphogenetic receptors (BMPRs)

\section{Introduction}

Macro-, micro-, and nanoscale extracellular matrix (ECM) organization provides a dynamic microenvironment to facilitate pivotal cell functions, including cell survival, migration, proliferation, and differentiation [1,2]. The biophysical roles of the ECM include being a critical regulator of stem cell behavior and function. The developmental fate of embryonic stem cells (ESCs) is also determined not only by soluble signaling molecules but also by the ECM contents, comprising the stem cell niche [3]. Since many biomaterials for tissue engineering and regenerative medicine aim to modulate the ECM, which governs stem cell differentiation and tissue construction, identifying biological ECM substitutes and how the engineered ECM governs stem cell performance is critical.

Recently, carbon-based materials have received increased attention in various biomedical engineering applications, such as osteogenesis [4], bone replacement [5], and drug 
delivery systems [6]. Graphene, a carbon-based nanomaterial with versatile physicochemical properties, has attracted increased research attention in various bio-engineering fields [7]. Graphene is a flat monolayer of carbon atoms patterned into a honeycomb, two-dimensional (2D) lattice, and it serves as a biocompatible and implantable platform for stem cell culture and artificial microenvironments [8-10]. Moreover, the biofunctionalized capability of graphene and its derivative, graphene oxide (GO), has highlighted these carbon nanomaterials in regenerative medicine and biotechnology studies [11,12]. GO has been shown to strengthen induced pluripotent stem cell (iPSC) growth and to promote spontaneous differentiation [10]. Graphene and GO encouraged the cardiomyogenic or neuronal differentiation of ESCs [13,14]. GO-filmed substrates also intensified the differentiation of mouse ESCs to the hematopoietic lineage [15]. Growing evidence has indicated that a graphene surface provides a biocompatible nanoscale to accelerate the differentiation of human mesenchymal stem cells (hMSCs) into a bone cell specification without cellular toxicity $[8,16,17]$. GO-incorporated poly (lactic-co-glycolic acid) (PLGA) nanofiber structures also enhance the proliferation and osteogenic differentiation of hMSCs [18]. Collectively, these results indicate the potential of graphene and GO-based biomaterials for stem cell-related biomedical applications.

Graphene and its derivatives significantly promote ECM-integrin clustering signaling and promote the long-term adhesion of human neuronal stem cells $[19,20]$. GO also strengthens the adherence of mouse ESCs in controlling the ESC differentiation potency [21]. Moreover, the integrin signaling pathway is involved in the biocompatibility of GO for the self-renewal of ESCs [22]. Many integrin-connected signaling networks influence not only cell adhesion to ECM substrates but also specific cell lineage commitments [23-25]. Thus, cell-graphene/GO substrate interactions can contribute to considerable cellular processes from the onset of adhesion operation.

Graphene and GO can be further functionalized by other biomaterials through various chemical bonds, such as covalent bonds, ionic bonds, and Van der Waals forces [26,27].

To establish effective strategies to fabricate functional matrixes or films, 3,4-dihydroxyL-phenylalanine (DOPA) derived from mussel adhesive threads has been used because of its extraordinarily adhesion properties [28]. Dopamine (DA), a catecholamine that contains catechol and amine functional groups, can self-polymerize to polydopamine (PDA) at an alkaline $\mathrm{pH}$ level, coating any virtual surface and presenting mussel-derived adhesive properties [28]. Based on these properties, PDA can be applied as an intermediate layer to deposit GO onto various substrates. Thus, this study employed PDA to securely attach GO nanosheets to the surface and manufactured carbon-based nanoscale ECM with GO and PDA hybrid materials (PDA/GO).

Although several studies have reported the involvement of GO in ESC self-renewal and differentiation into the hematopoietic or neuronal lineage, to date, few studies have investigated the influences of GOs on the osteogenic differentiation of ESCs. The present study investigated how the PDA/GO composite substrate influences the osteogenic differentiation of ESCs. Moreover, the interaction of ESCs and this engineered microenvironment was demonstrated by certain signaling mechanisms to promote and control the fate of ESCs.

\section{Results}

\subsection{PDA/GO Substrate Promotes the Osteogenic Differentiation of ESCs}

The morphology of the patterned PDA/GO substrate was first observed by SEM. The SEM images demonstrated a relative PDA coating or multilayered PDA/GO layer on the substrate (Figure 1A). The atomic constitution by XPS indicated that C1s is the most predominant element on the PT surface. The PDA-coated surface demonstrated increased concentrations of O1s and N1s compared with that on the PT surface. When PDA/GO was deposited on the surfaces, the concentrations of $\mathrm{C} 1 \mathrm{~s}$ and $\mathrm{O} 1 \mathrm{~s}$ were increased compared with those on the PDA surface (Figure 1B). These results suggest that the PDA or PDA/GO substrate was successfully immobilized on the PT culture surface. 


\section{A}

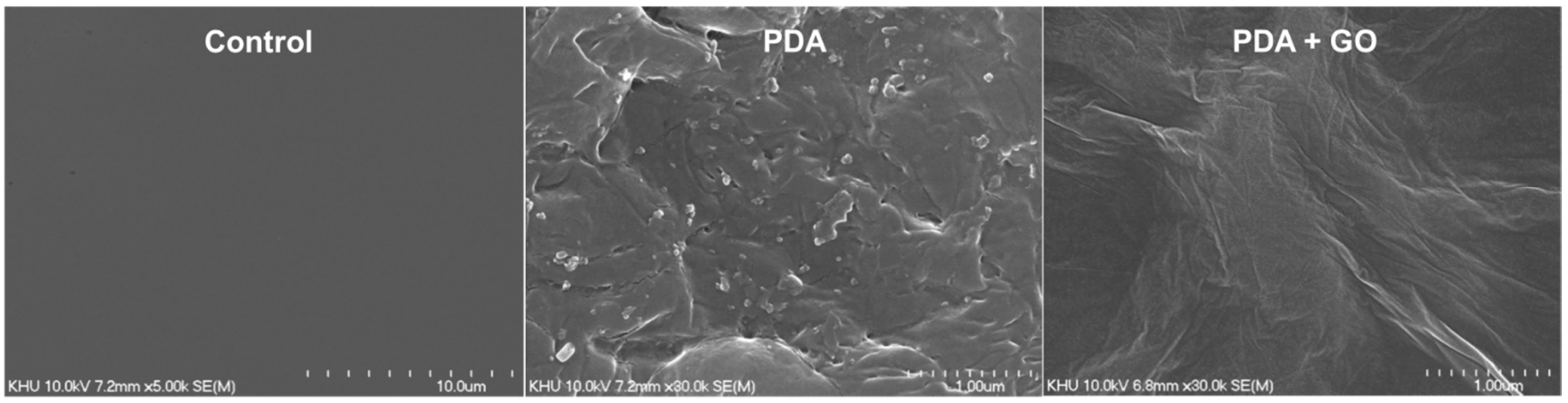

B

\begin{tabular}{cccc}
\hline Substrates & C1s \% & 01s \% & N1s \% \\
\hline Control & 87.7 & 5.1 & - \\
PDA & 75.2 & 19.7 & 7.8 \\
PDA + GO & 78.6 & 22.1 & 6.9 \\
\hline
\end{tabular}

Figure 1. Surface characterization of PDA/GO substrates. (A) Topographical features of the PT surface, PDA (1 mg/mL)coated, and PDA/GO $(1 \mathrm{mg} / \mathrm{mL}+1 \mathrm{mg} / \mathrm{mL})$-coated surfaces were assessed by scanning electron microscopy at $\times 10 \mathrm{k}$ magnification. (B) Relative atomic composition of each sample.

Before observing the osteogenic response of ESCs, cell viability on PDA/GO was first assessed after cells were cultured on PDA/GO-coated $(0.1,0.5,1 \mathrm{mg} / \mathrm{mL})$ or uncoated (control) surfaces for 1, 5, 10, and 14 days. No difference was found in the cell viability between ESCs cultured on the PDA/GO and control surface, indicating no cytotoxicity of the present combination of PDA/GO substrates (Figure 2A). Subsequently, the osteogenic differentiation of ESCs was explored by analyzing the ALP activity and intracellular calcium levels $\left(\left[\mathrm{Ca}^{2+}\right]_{\mathrm{i}}\right)$. The ALP activity in cells on the PDA/GO substrate was increased compared with those of the control group on day 4 and was further increased on day 7 (Figure 2B). Similar to ALP activity, the $\left[\mathrm{Ca}^{2+}\right]_{\mathrm{i}}$ was also increased in cells on PDA/GO in a dose-dependent manner (Figure 2C). Extracellular calcium deposits were also analyzed. Figure 2D indicates that calcium deposits were increased in ESCs on the PDA/GO substrate compared with those of the control groups (Figure 2D). The osteogenic effect of the PDA/GO substrate was assessed by following the gene and protein expression of the osteogenic markers. The mRNA expression of osteogenic target genes (ALP, osterix (OSX), runt-related transcription factor 2 (RUNX2), osteocalcin (OCN), and osteopontin (OPN)) was increased in cells on a PDA/GO coating compared with that of the control group and showed the highest level in cells on $1 \mathrm{mg} / \mathrm{mL}$ of PDA/GO (Figure 3A-E). Western blot analysis also showed that OCN and OSX protein levels were increased in cells cultured on PDA/GO substrate on day 7 of osteogenic induction (Figure 3F,G). 
A

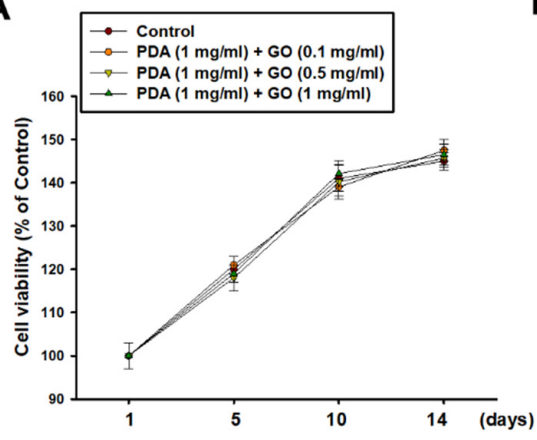

B

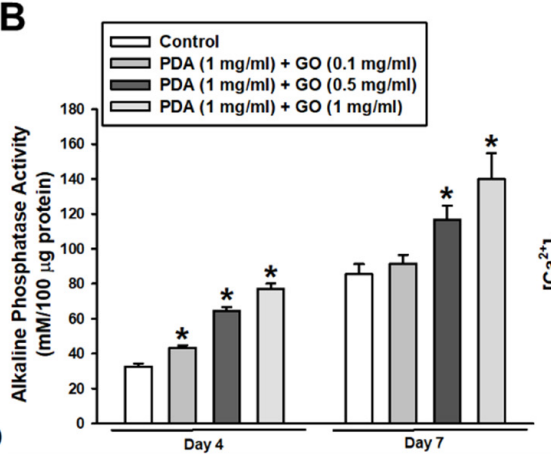

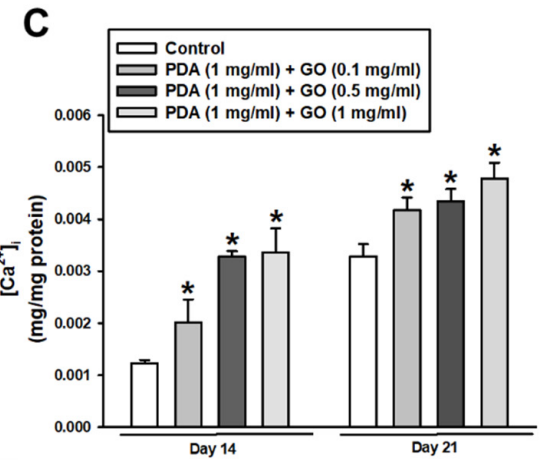

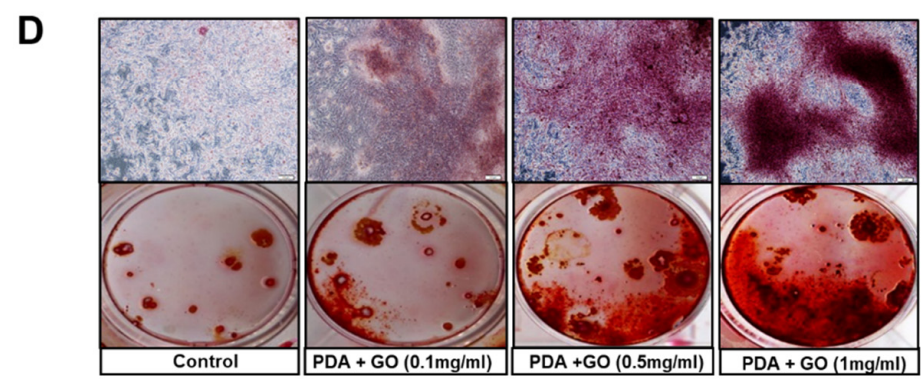

Figure 2. Osteogenic differentiation of ESCs cultured on PDA/GO-modified surfaces. (A) Cells were cultured on the PDA/GO substrate (composite of PDA with $1 \mathrm{mg} / \mathrm{mL}$ and variable GO concentration with $0.1,0.5$, or $1 \mathrm{mg} / \mathrm{mL}$ ) for 1, 5, 10, and 14 days, and then, the cell viability was assessed as described in the Materials and Methods. (B) ALP activity, (C) $\left[\mathrm{Ca}^{2+}\right]_{\mathrm{i}}$, and (D) Alizarin Red S staining were evaluated after 4, 7, 14, or 21 days of osteogenic induction. The values are presented as means $\pm \mathrm{SD}(n=3) .{ }^{*} p<0.05$ vs. the control value at each time point.

\subsection{Integrin $\alpha 5 / \beta 1$ and BMPR I/II Signaling Pathways in ESCs on the PDA/GO Substrate}

To understand the molecular mechanisms underlying the link between ESCs and the PDA/GO substrate, we explored whether integrins, as an adhesion receptor, and bone morphogenetic protein receptors (BMPRs), as representative osteogenic-functioning receptors, are associated with PDA/GO substrate-derived ESC-osteolineage commitment. The protein levels of integrins were analyzed in cells cultured on the PDA/GO substrate after 7 days of culture (Figure $4 \mathrm{~A}$ ). The $\alpha 5$ and $\beta 1$ subunits of integrins showed increased protein levels in cells on the PDA/GO substrate compared with those in the control groups (Figure 4A). These increases were dose dependent according to the GO concentration. Western blot analysis showed that the type I and II BMPR levels were significantly increased when cells were cultured on the PDA/GO substrate (Figure 4B). SMAD 1/5/8 are signal transducers, which are activated by BMP receptors and mediate BMP signaling pathways. SMAD1/5/8 phosphorylation was elevated in cells on the PDA/GO substrate than in the control (Figure $4 \mathrm{~B}, \mathrm{C}$ ). The nuclear translocation of SMAD1/5/8 was also confirmed using immunofluorescence staining (Figure 4D). Thus, activation of the BMPR-SMAD1/5/8 signaling pathway may provide an additional osteoinductive signal for ESC-osteogenic differentiation on the PDA/GO substrate. 

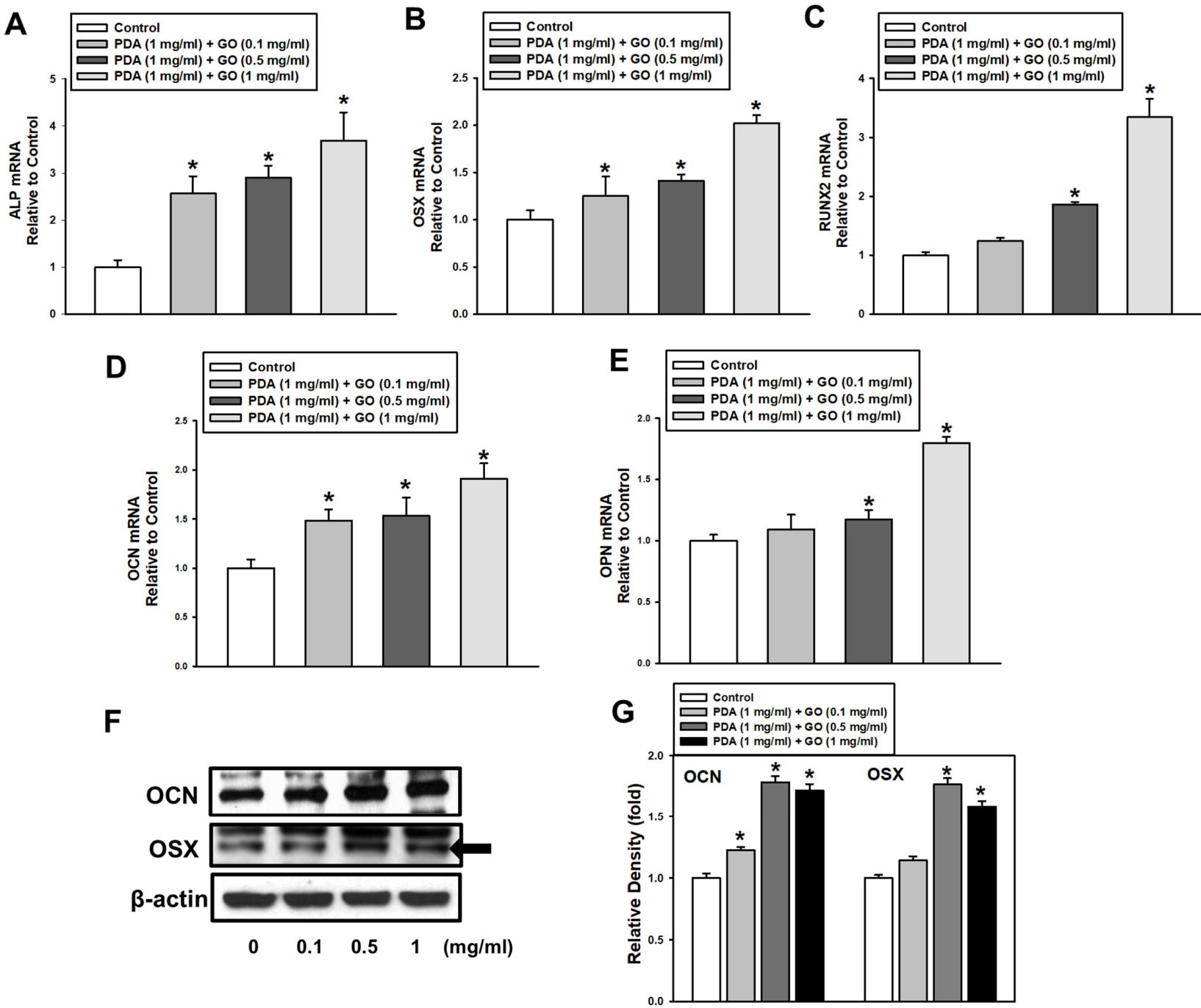

Figure 3. Effect of PDA/GO on osteogenic-related gene and protein expression. (A-E) The mRNA expression of ALP, OSX, RUNX2, OCN, and OPN was analyzed after 7-day osteogenic induction by real-time RT-PCR. (F) The protein levels of OCN $(5.5 \mathrm{kDa})$ and OSX (45 kDa) were determined by Western blot. $(\mathrm{G})$ The bars denote the density relative to $\beta$-actin. The values are expressed as means $\pm \operatorname{SD}(n=3) .{ }^{*} p<0.05$ vs. control value.

This study also examined whether ESC osteogenic differentiation on the PDA/GO substrate requires the activation of mitogen-activated protein kinases (MAPKs), which are responsible for osteogenic differentiation and bone formation $[29,30]$. The activation of MAPKs, such as extracellular signal-regulated kinase (ERK)1/2, p38, and c-Jun-N-terminal kinase (JNK), was assessed by measuring the phosphorylated form of each MAPK using Western blot analysis (Figure 5A). The expression of P-ERK1/2, P-p38, and P-JNK was upregulated in cells on the PDA/GO substrate compared with that in the control. No significant differences were found in the expression of total ERK1/2, p38, and JNK among all the experimental groups. To further understand this extracellular-leading intracellular signaling pathway, the influence of integrin $\alpha 5 / \beta 1$ in MAPK activation was evaluated using integrin $\alpha 5 / \beta 1$ siRNA. The knockdown efficiency of integrin $\alpha 5 / \beta 1$ siRNA was first confirmed when the transfection of integrin $\alpha 5 / \beta 1$ siRNA downregulated the protein levels of each integrin in cells on the PDA/GO substrate (Figure $5 \mathrm{~B})$. The phosphorylation of ERK1/2, p38, and JNK was decreased by the knockdown of integrin $\alpha 5 / \beta 1$, indicating that integrin $\alpha 5 / \beta 1$ mediates MAPK signaling pathways during ESC osteogenic differentiation in response to the PDA/GO substrate. 
A

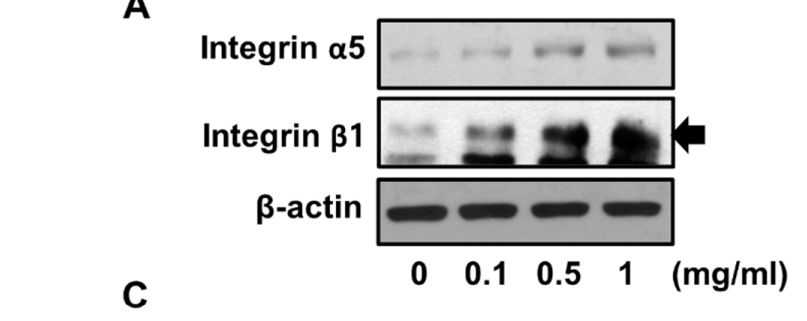

B

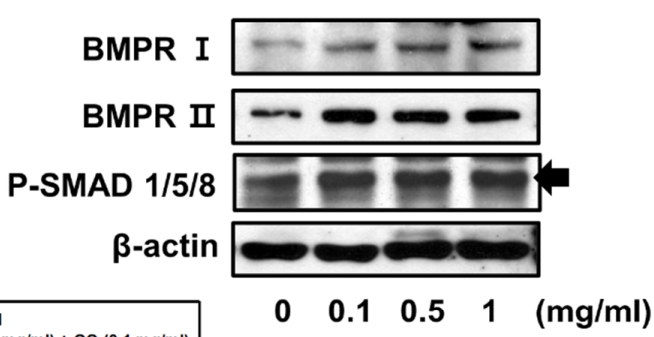

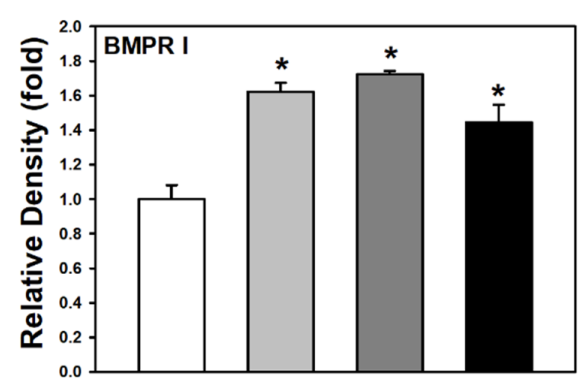
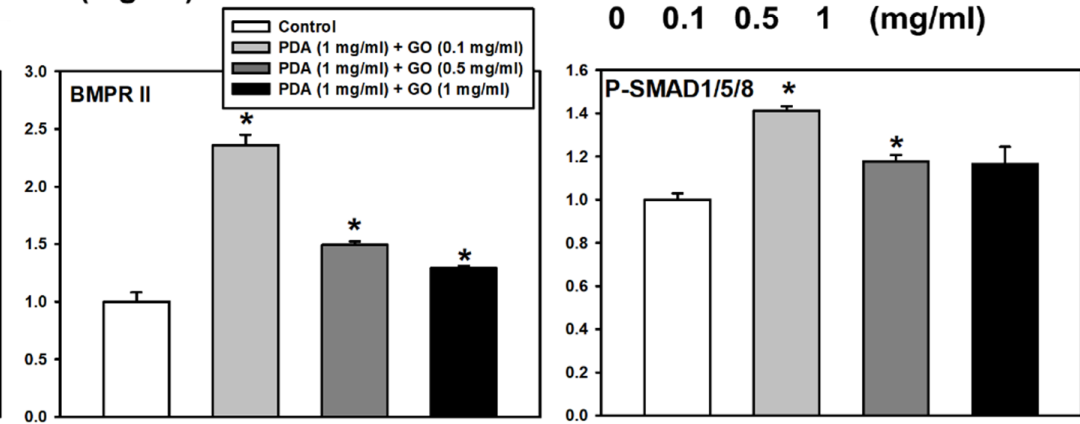

D

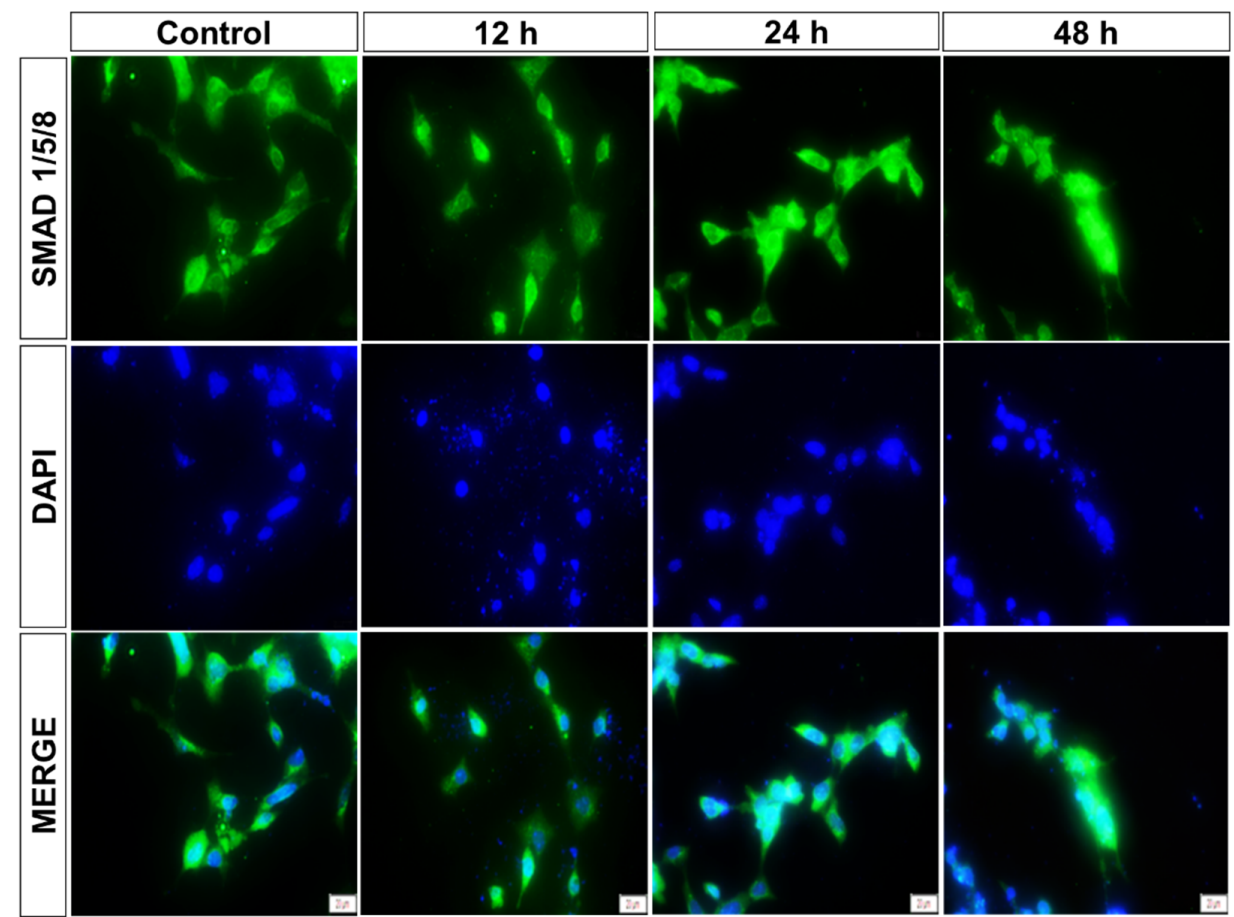

Figure 4. Effect of PDA/GO on integrin $\alpha 5 / \beta 1$, MAPKs, BMPR I/II, and SMAD $1 / 5 / 8$ signaling pathways. The cells were cultured on the PDA/GO substrate for 7 days, and the protein levels of $(\mathbf{A})$ integrin $\alpha 5$ (138 kDa), integrin $\beta 1(150 \mathrm{kDa})$, and (B) BMPR I (50-55 kDa), BMPR II (115 kDa), and phosphorylation levels of SMAD 1/5/8 (52-56 kDa) were analyzed. (C) The bars denote the density relative to $\beta$-actin. The values are expressed as means $\pm \operatorname{SD}(n=3)$. ${ }^{*} p<0.05 \mathrm{vs}$. control value. (D) Nuclear translocation of SMAD 1/5/8 was assessed by immunofluorescence staining (scale bar, $20 \mu \mathrm{m}$ ). 
A

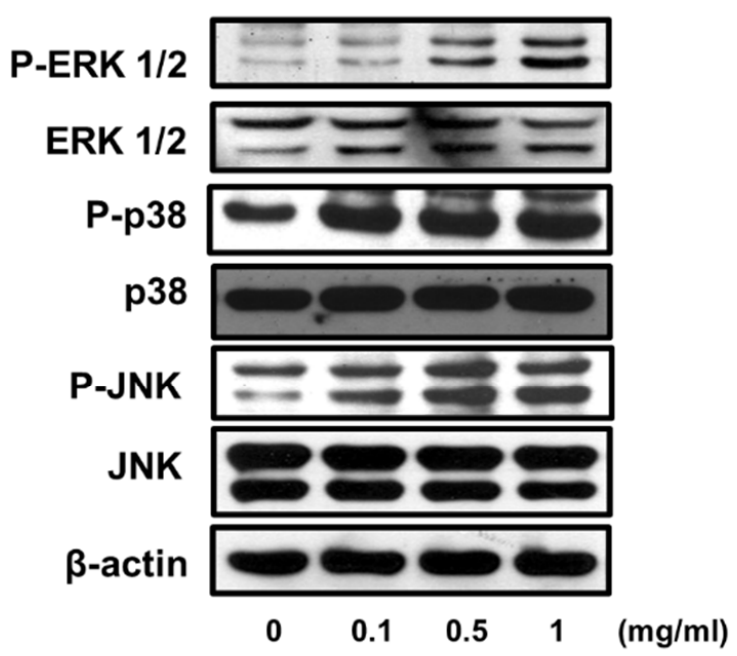

B

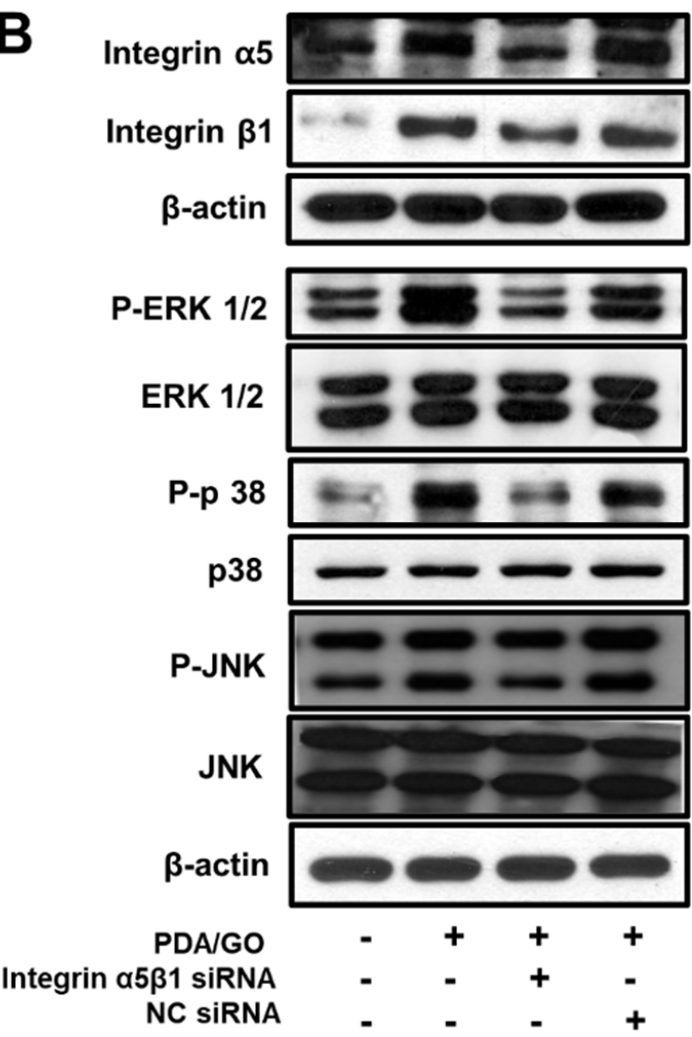

Figure 5. Effect of PDA/GO on MAPKs signaling pathways. The cells were cultured on the PDA/GO substrate for 7 days and (A) Phosphorylation of ERK1/2 (42-44 kDa), p38 (38 kDa), and JNK (46-54 kDa) was assessed. (B) Cells were transfected with integrin $\alpha 5 / \beta 1$-specific siRNA, and the protein levels of integrin $\alpha 5, \beta 1$, and the ERK1/2, p38, and JNK phosphorylation levels were examined after 4 days of osteogenic induction.

2.3. Integrin $\alpha 5 / \beta 1, M A P K s$, and BMPRs/SMAD Mediate ESC Osteogenic Differentiation on the PDA/GO Substrate

Considering that the activation of integrin $\alpha 5 / \beta 1$, MAPK, and BMPR/SMAD signaling pathways is related to PDA/GO-derived ESC osteogenesis, we investigated the influence of individual pathways in the osteogenic differentiation of ESCs on the PDA/GO substrate. Figure $6 \mathrm{~A}$ demonstrates that the knockdown of integrin $\alpha 5 / \beta 1$ reduced the PDA/GO-induced ESC ALP activity. Western blot analysis confirmed the downregulation of OCN and OSX protein levels after integrin $\alpha 5 / \beta 1$-knockdown (Figure $6 \mathrm{G}$ ). Next, the connection between MAPK activation and PDA/GO-derived ESC osteogenesis was examined. When cells were treated with ERK inhibitor (PD98059), p38 inhibitor (SB203580), JNK inhibitor (SP600125), or SMAD inhibitor (SB431542), the ALP activity and $\left[\mathrm{Ca}^{2+}\right]_{\mathrm{i}}$ of ESCs cultured on the PDA/GO were downregulated (Figure 6B-F), as well as OCN and OSX protein levels (Figure $6 \mathrm{H}-\mathrm{K}$ ). Calcium deposits were also decreased in ESCs on the PDA/GO substrate with each inhibitor (Figure 6L). 

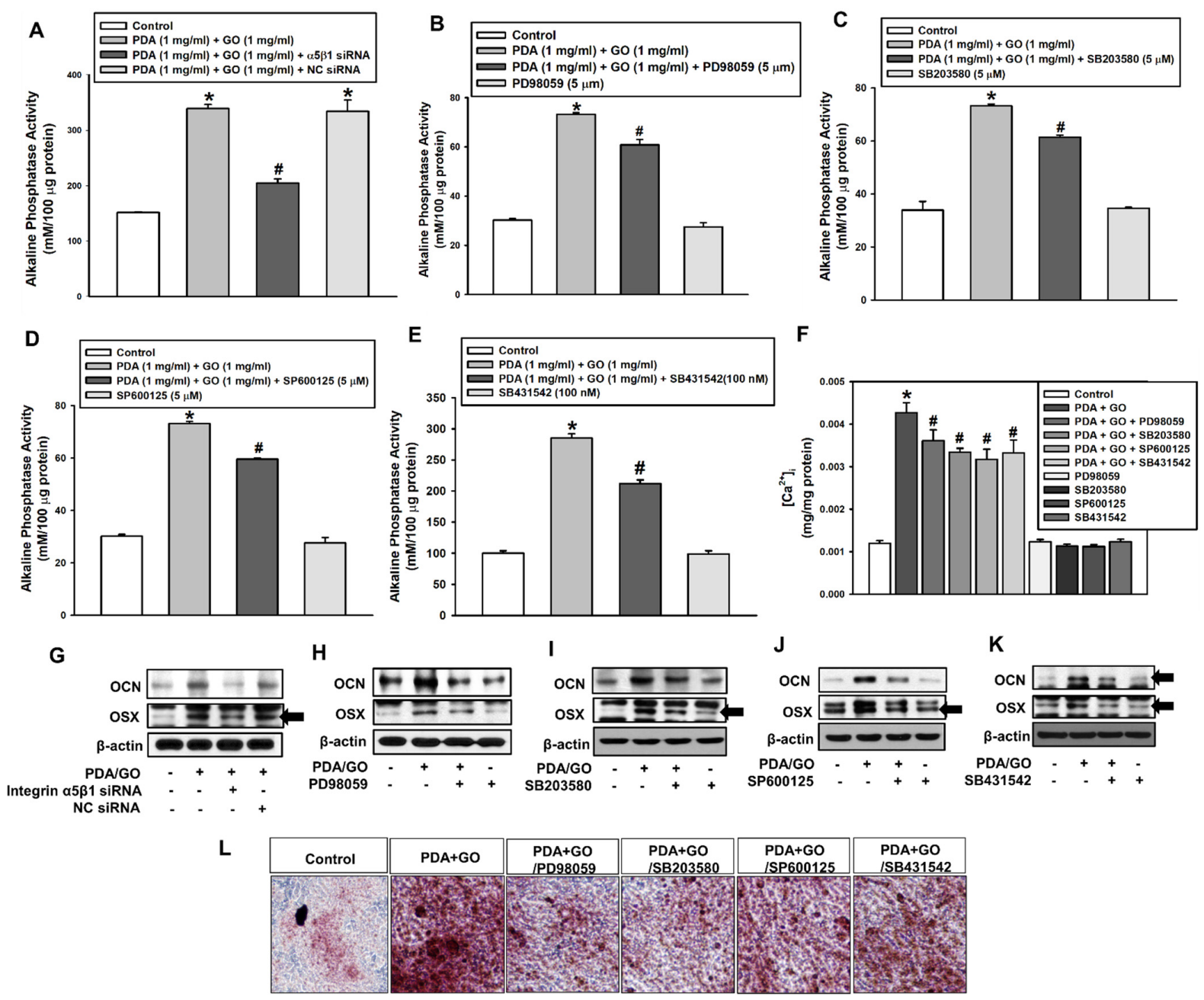

Figure 6. Role of the integrin $\alpha 5 / \beta 1$, MAPK, and BMPR/SMAD signaling pathways in the PDA/GO-mediated osteogenic differentiation of ESCs. Cells were transfected with integrin $\alpha 5 / \beta 1$-specific siRNA, or treated with PD98059 (5 $\mu \mathrm{M})$,

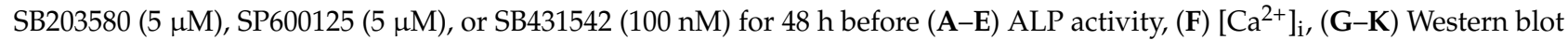
analysis, and (L) Alizarin Red S staining. The values are expressed as means $\pm \operatorname{SD}(n=4) .{ }^{*} p<0.05$ vs. each control value, and ${ }^{\#} p<0.05$ vs. PDA/GO value.

\section{Discussion}

The present study showed that a PDA/GO composite-coated cell culture substrate can effectively contribute to ESC osteogenic differentiation through the integrin $\alpha 5 / \beta 1$, MAPK, and BMPR/SMAD signaling pathways. There is an increased demand for optimized microenvironmental systems to maintain self-renewal or facilitate the differentiation of adult and embryonic stem cells [31,32]. Previous studies have shown that novel biomaterials that imitate the extracellular microenvironment and in vivo construction encourage the efficient differentiation of stem cells to the desired cell lineage [33,34]. Thus, the present study demonstrated that the culture of ESCs on the PDA/GO-coated surface promotes osteogenic differentiation of ESCs. Few studies have investigated the osteogenic effect of the PDA/GO composite on ESCs and even on MSCs. One study showed that a PDA-inspired GO and titanium scaffold promoted bone marrow-derived MSC adhesion and proliferation, as well as development of nanostructured environments for bone regeneration [35]. Our PDA/GO-functionalized culture substrate is a potential strategy to produce large numbers of osteogenic cells from ESCs.

The interplay between stem cells and the engineered extracellular microenvironment for a practical stem cell differentiation system must be investigated further. The present 
study provides the underlying molecular processes for ESC osteogenic differentiation on a physicochemical PDA/GO substrate. The first cue mediating the mechanical signal of PDA/GO to ESCs was the cell surface receptors integrin $\alpha 5 / \beta 1$ in the present study. Previous studies have shown that the gene and protein expression levels of integrin $\alpha 5 / \beta 1$ were increased during human MSC differentiation to osteoblasts [36-38]. Osteoblast adhesion on certain ECM proteins was achieved through binding to $\alpha \mathrm{v} \beta 1$ integrin [39]. Various studies have demonstrated that dynamic expression of different integrins is required for the osteogenic differentiation of MSCs [40,41]. The use of graphene material suggests the pivotal role of integrin $\beta 1$ in ECM roughness recognition, which is involved in osteoblast maturation and MSC differentiation on graphitic carbon-coated surfaces [42]. Other reports have shown that the protein expression of integrin $\beta 1$ is increased on graphene-coated $\mathrm{Si} / \mathrm{SiO}_{2}$ substrates by significantly promoting the differentiation of MSCs into bone cells [8]. Integrin $\beta 1$ binds 12 different $\alpha$ subunits, including the $\alpha 5$ subunit, in osteoblasts and osteoprogenitor cells. Moreover, integrin $\beta 1$ mediates cell adhesion to bone matrix and promotes osteogenic cell proliferation and differentiation, indicating that integrin $\beta 1$ signaling plays a major function in bone formation $[43,44]$. To date, numerous studies have shown that integrins $\alpha 5 / \beta 1$ participate in the osteogenic differentiation of osteoprogenitors and MSCs as previously mentioned. We also suggest that integrin $\alpha 5 / \beta 1$ can introduce the differentiation of ESCs into the osteogenic lineage when they are cultured on the PDA/GO substrate.

In the present study, integrin $\alpha 5 / \beta 1$ led to the activation of ERK1/2, p38, and JNK MAPKs as outside-relayed intracellular pathways during ESC osteogenic differentiation in response to PDA/GO. These MAPKs are the best-characterized downstream signaling pathways of the matrix microenvironment-integrin interactions in osteogenic cell types [44-46]. Consistent with the current results, MAPKs have been frequently reported as a key player for the osteogenic differentiation of various types of stem cells [47-49]. Regarding previous studies and our findings, these integrin-MAPK stepwise processes trigger the osteogenic induction of ESCs in response to the PDA/GO culture substrate.

Interestingly, the BMP receptors, members of the transforming growth factor- $\beta$ (TGF$\beta$ ) superfamily, were suggested as the other cell-receiving signals from the PDA/GO substrate. GO mechanistically interacts with multiple cell surface receptors [50-52]. However, the PDA or GO material can activate BMP receptors in ESCs or other stem cell models. One previous study reported that GO activated TGF- $\beta$ receptor/SMAD2/3 signaling to trigger new metastases of human cancer cells [53]. Insufficient data exist to identify PDA/GO-related osteogenic signaling pathways; however, our findings showed that the PDA/GO substrate facilitates the presentation of BMP receptors in ESCs and enhances ESC osteogenic activity. BMPRs and canonical SMAD signaling are widely studied in the bone biology field [54-56]. Several studies have verified that SMAD-dependent BMP and TGF- $\beta$ signaling pathways manage both osteoblast and osteoclast function; thus, they play potential roles in skeletal development, bone formation, and bone homeostasis [57-60]. The present study demonstrated increased BMPR type I and II protein levels and activation of SMAD 1/5/8, receptor-regulated SMADs (R-SMADs), which are responsible for PDA/GO-derived ESC differentiation into osteolineage cells. A previous study reported that BMPR recognition and the phosphorylation of SMAD 1/5/8 signaling promoted the in vitro osteogenic differentiation of $\mathrm{C} 2 \mathrm{C} 12$ cells in a magnesium-modified calcium phosphate matrix model [61]. Thus, the designed ECM substrates sensing the BMPR/SMAD signaling axis enable biomaterials to attend osteoinductive performance.

Although the present study suggests a model for ESC osteogenic differentiation on PDA/GO composite by the initiation of both integrin $\alpha 5 / \beta 1$ and BMPRs, the reciprocal interactions between these receptors is still unclear. Further study of this ambiguous issue is warranted.

This study systematically investigated the osteogenic bioactivity of PDA/GO composite as a substrate material with ESCs. When ESCs were cultured on PDA/GO substrates, cells significantly exhibited the osteogenic differentiation through integrin $\alpha 5 / \beta 1$, MAPK, 
and BMPR I/II-SMAD 1/5/8 signaling pathways (Figure 7). Finally, the PDA/GO culture system may provide a stem cell niche-mimetic environment to control stem cell fate and a facile and promising strategy for bone tissue engineering and regenerative medicine.

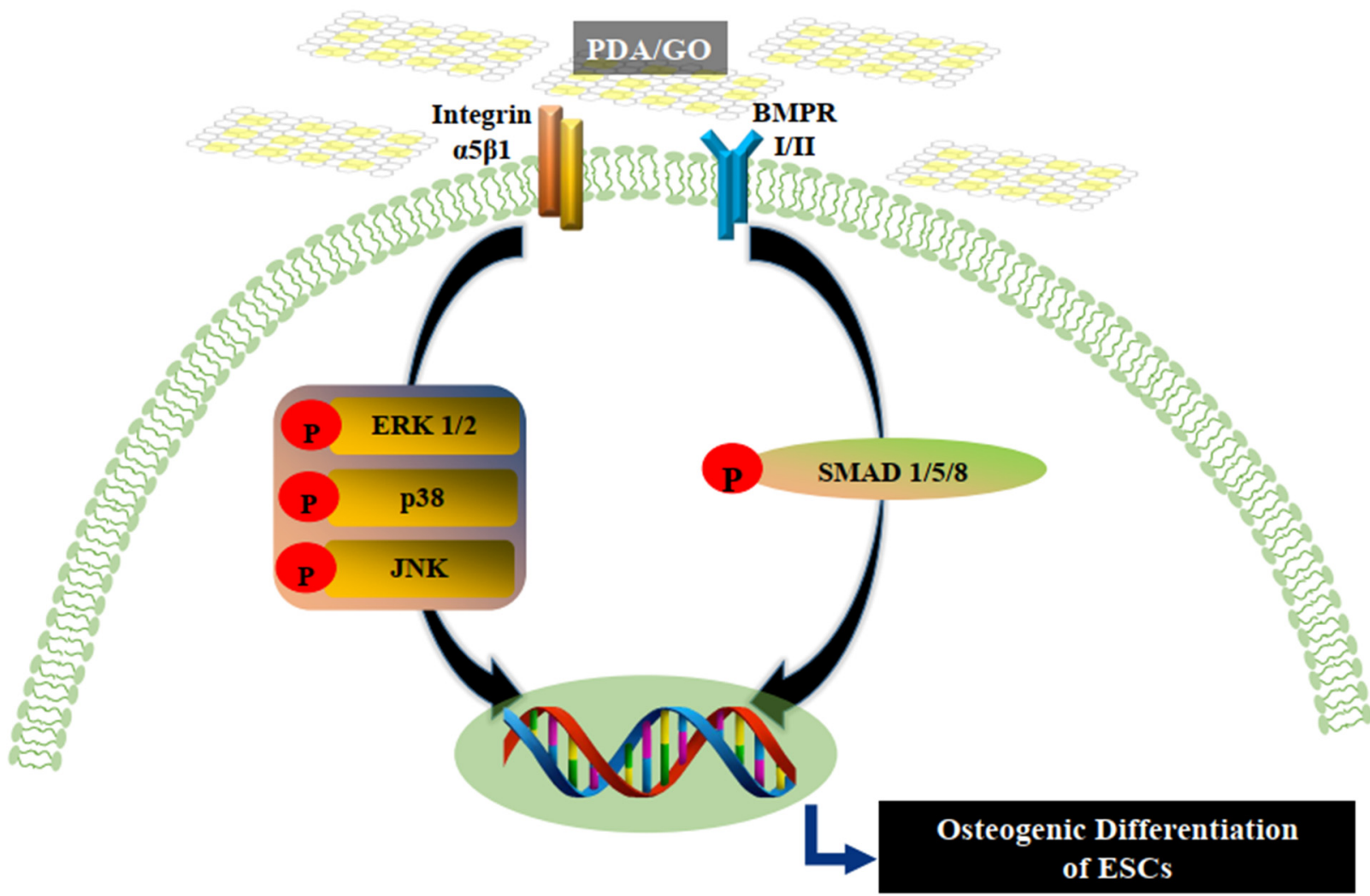

Figure 7. Hypothesized model of the PDA/GO-mediated osteogenic differentiation of ESCs. When ESCs are cultured on PDA/GO-modified surfaces, integrin $\alpha 5 / \beta 1$ and BMPR I/II are recognized, leading to MAPK or SMAD signaling pathway activation and eventually promoting the osteogenic differentiation of ESCs.

\section{Materials and Methods}

\subsection{Materials}

Fetal bovine serum (FBS) was supplied by Gibco-BRL (Gaithersburg, MD, USA). Antibodies used for Western blot analysis and immunofluorescence staining were obtained from Santa Cruz Biotechnology (Santa Cruz, CA, USA). The chemicals, including L-3,4dihydroxyphenylalanine (L-DOPA) and graphene oxide dispersion, were purchased from Sigma Chemical Company (St. Louis, MO, USA). Other laboratory materials were acquired from SPL Lifescience (Pocheon, Korea).

\subsection{Mouse ESC Culture and Embryoid Body Formation}

Mouse ESCs (ES-E14TG2a (ATCC ${ }^{\circledR}$ CRL-1821 $\left.{ }^{\mathrm{TM}}\right)$ ) were supplied from the American Type Culture Collection (Manassas, VA, USA). ESC culture was performed as in our previous report [62]. To develop embryoid bodies (EBs), dissociated cells were aggregated by hanging drop with 2000 cells in $20 \mu \mathrm{L}$ of DMEM. We used 5-day-old EBs in every experiment.

\subsection{Preparation of the PDA/GO Composite Substrate}

The PDA solution was prepared by dissolving $1 \mathrm{mg}$ of L-DOPA in $1 \mathrm{~mL}$ of $10 \mathrm{mM}$ Tris buffer base ( $\mathrm{pH}$ 8.5; Sigma-Aldrich, St. Louis, MI, USA). Then, GO dispersion was added to the PDA solution $(1 \mathrm{mg} / \mathrm{mL})$ under magnetic stirring at room temperature for $24 \mathrm{~h}$. The final concentration of GO in the PDA solution was $0.1,0.5$, or $1 \mathrm{mg} / \mathrm{mL}$ for 
individual experiments. The polystyrene (PT) culture surface was coated with PDA/GO composite solution overnight at room temperature and washed three times with sterile phosphate-buffered saline (PBS). Then, the PDA/GO-modified surfaces were dried in a vacuum oven.

\subsection{Characterization of the PDA/GO-Coated Surface}

Images of PDA/GO composite-coated surfaces were identified with scanning electron microscopy (SEM; S-4700, Hitachi, Tokyo, Japan). The specimens were rinsed with PBS and then freeze-dried overnight before SEM operation. The atomic composition of the PDA/GO-modified surfaces was assessed by X-ray photoelectron spectroscopy (XPS) as in our previous report [63]. The surface composition amount was obtained from the XPS survey spectra.

\subsection{Cell Viability Assay}

Cell viability was performed using the cell counting kit-8 (CCK-8) assay as in our previous report [62]. Briefly, cells were cultured on PDA/GO substrate $(0,0.1,0.5,1 \mathrm{mg} / \mathrm{mL})$ for $1,5,10$, and 14 days, and the CCK-8 assay was performed according to the manufacturer's instructions. The optical density was observed at a wavelength of $450 \mathrm{~nm}$ using an ELISA reader system (Triad; DYNEX, Chantilly, VA, USA). The proportion of cell viability was designated relative to the control.

\subsection{Alkaline Phosphatase Activity Assay}

Alkaline phosphatase activity was assessed as in our previous report [62]. Briefly, cells were plated onto PDA/GO composite-coated $60 \mathrm{~mm}$ dishes (10-15 EBs per dish). ALP activity was evaluated after 4 and 7 days of osteogenic induction using the $p$-nitrophenylphosphate (pNPP) procedure. The ALP enzyme activity was denoted as mM/100 $\mu \mathrm{g}$ of protein.

\subsection{Intracellular Calcium Quantification Assay}

Quantification of the intracellular calcium level was evaluated based on our previous report [62]. Briefly, cells were plated onto PDA/GO composite-coated $60 \mathrm{~mm}$ dishes (10-15 EBs per dish). Fourteen and twenty-one days after osteogenic induction, the intracellular calcium concentration was measured using a calcium assay kit (BioAssay Systems, Hayward, CA, USA) according to the manufacturer's information. The optical density was read at $612 \mathrm{~nm}$. The calcium level was expressed as $\mathrm{mg} / \mathrm{mg}$ of protein.

\subsection{Alizarin Red Staining}

Alizarin Red staining was achieved as described in our previous report [64]. The cells were fixed with $4 \%$ paraformaldehyde for $15 \mathrm{~min}$ and rinsed three times with PBS. Then, the cells were stained with $2 \%$ Alizarin Red S solution ( $\mathrm{pH} 4.2)$ for $5 \mathrm{~min}$, and unbound dye residue was washed with PBS. The stained images of different surfaces were observed using a light microscope.

\subsection{Osteogenic-Related Gene Expression Analysis}

Real-time reverse transcription-polymerase chain reaction (RT-PCR) was conducted as in our previous report [62] to measure the mRNA expression of osteogenic genes. The primers used were as follows: 5'-GAC TGG TAC TCG GAT AAC GA-3' (forward) and 5' TGC GGT TCC AGA CAT AGT GG-3' (reverse) for ALP; $5^{\prime}$-CCAACTTCCTGTGCTCCGTG$3^{\prime}$ (forward) and 5'-TCTTGCCTCGTCCGCTCC-3' (reverse) for Runx2; 5'-TGA AAC GAG TCA GCT CTG GAT G-3' (forward) and 5'-TGA AAT TCA TGG CTG TGG AA-3' (reverse) for OPN; 5'-TGA GGA GGA AGT TCA CTA TGG-3' (forward) and 5'-TTC TTT GTG CCT GCT TTG C-3' (reverse) for OSX; 5'-ATG AGA GCC CTC ACA CTC CTC-3' (forward) and 5'-GCC GTA GAA GCG CCG ATA GGC-3' (reverse) for OCN; and 5'-GCT CTC CAG AAC ATC ATC C-3' (forward) and 5'-TGC TTC ACC ACC TTC TTG-3' (reverse) for GAPDH. 


\subsection{Western Blot Analysis}

Western blot analysis was performed as in our previous report [63]. Briefly, the primary (anti-OCN, anti-OSX, anti-integrin $\alpha 5$, anti-integrin $\beta 1$, anti-BMPR I, anti-BMPR II, anti-SMAD1/5/8, anti-P-SMAD1/5/8, anti-ERK1/2, anti-P-ERK1/2, anti-p38, antiP-p38, anti-JNK, anti-P-JNK, or anti- $\beta$-actin; Santa Cruz Biotechnology) and secondary antibodies (goat anti-rabbit immunoglobulin $\mathrm{G}(\mathrm{IgG})$ or goat anti-mouse IgG conjugated to horseradish peroxidase) were employed with the dilutions recommended by the supplier. The blots were developed using enhanced chemiluminescence (Santa Cruz Biotechnology) and developed using X-ray film (Eastman-Kodak, Rochester, NY, USA).

\subsection{Immunofluorescence Staining}

Nuclear translocation of SMAD1/5/8 was detected by time-dependent immunofluorescence staining. The cells were incubated with SMAD1/5/8 antibodies at $4{ }^{\circ} \mathrm{C}$ overnight and then with Alexa Fluor 488 goat anti-rabbit IgG for $2 \mathrm{~h}$. Fluorescence images were developed using a fluorescence microscope (Fluoview 300; Olympus, Tokyo, Japan).

\subsection{SiRNA Transfection}

Small interfering RNA (siRNA) transfection was conducted as in our previous report [64]. Briefly, the cells were transfected with either an integrin $\alpha 5 / \beta 1$ siRNA ( $25 \mathrm{nM})$ or a negative control siRNA (scrambled) for $48 \mathrm{~h}$ using a transfection reagent (RNAiMAX, Invitrogen, Waltham, MA, USA) according to the manufacturer's manual before being subjected to ALP activity and Western blot analysis.

\subsection{Statistical Analysis}

All the data were expressed as means \pm standard deviation. One-way analysis of variance was used for multiple comparisons (Duncan's multiple range test). Analyses were obtained using SPSS software (ver. 10.0; SPSS Inc., Chicago, IL, USA). A $p$-value $<0.05$ were considered statistically significant.

Author Contributions: Conceptualization, J.S.H.; Methodology and Investigation, N.Y.S.; Data Curation, J.S.H. and N.Y.S.; Writing, original draft preparation, J.S.H.; Visualization, N.Y.S.; Supervision, J.S.H.; Project Administration, J.S.H.; Funding Acquisition, J.S.H. All authors have read and agreed to the published version of the manuscript.

Funding: This work was supported by a National Research Foundation of Korea (NRF) grant funded by the Korea government (MSIP) (No. 2018R1D1A1B07047538).

Institutional Review Board Statement: Not applicable.

Informed Consent Statement: Not applicable.

Data Availability Statement: Not applicable.

Conflicts of Interest: The authors declare no conflict of interest.

\section{References}

1. Daley, W.P.; Peters, S.B.; Larsen, M. Extracellular matrix dynamics in development and regenerative medicine. J. Cell Sci. 2008, 121, 255-264. [CrossRef] [PubMed]

2. Kerativitayanan, P.; Carrow, J.K.; Gaharwar, A.K. Nanomaterials for engineering stem cell responses. Adv. Healthc. Mater. 2015, 411, 1600-1627. [CrossRef] [PubMed]

3. Czyz, J.; Wobus, A. Embryonic stem cell differentiation: The role of extracellular factors. Differentiation 2001, 68, 167-174. [CrossRef] [PubMed]

4. Xu, A.; Liu, X.; Gao, X.; Deng, F.; Deng, Y.; Wei, S. Enhancement of osteogenesis on micro/nano-topographical carbon fiberreinforced polyetheretherketone-nanohydroxyapatite biocomposite. Mater. Sci. Eng. C Mater. Biol. Appl. 2015, 48, 592-598. [CrossRef]

5. Bennett, D.B.; Hill, J.C.; Dennison, J.; O’Brien, S.; Mantel, J.L.; Isaac, G.H.; Beverland, D.E. Metal-carbon fiber composite femoral stems in hip replacements: A randomized controlled parallel-group study with mean ten-year follow-up. J. Bone Jt. Surg. Am. 2014, 96, 2062-2069. [CrossRef] [PubMed] 
6. Chen, J.; Chen, S.; Zhao, X.; Kuznetsova, L.V.; Wong, S.S.; Ojima, I. Functionalized single-walled carbon nanotubes as rationally designed vehicles for tumor targeted drug delivery. J. Am. Chem. Soc. 2008, 130, 16778-16785. [CrossRef]

7. Zhu, Y.; Murali, S.; Cai, W.; Li, X.; Suk, J.W.; Potts, J.R.; Ruoff, R.S. Graphene and graphene oxide: Synthesis, properties, and applications. Adv. Mater. 2010, 22, 3906-3924. [CrossRef]

8. Nayak, T.R.; Andersen, H.; Makam, V.S.; Khaw, C.; Bae, S.; Xu, X.; Ee, P.L.; Ahn, J.H.; Hong, B.H.; Pastorin, G.; et al. Graphene for controlled and accelerated osteogenic differentiation of human mesenchymal stem cells. ACS Nano 2011, 5, 4670-4678. [CrossRef]

9. Lee, W.C.; Lim, C.H.; Shi, H.; Tang, L.A.; Wang, Y.; Lim, C.T.; Loh, K.P. Origin of enhanced stem cell growth and differentiation on graphene and graphene oxide. ACS Nano 2011, 5, 7334-7341. [CrossRef]

10. Chen, G.Y.; Pang, D.W.; Hwang, S.M.; Tuan, H.Y.; Hu, Y.C. A graphene based platform for induced pluripotent stem cells culture and differentiation. Biomaterials 2012, 33, 418-427. [CrossRef]

11. Cai, Y.; Li, H.; Du, B.; Yang, M.; Li, Y.; Wu, D.; Zhao, Y.; Dai, Y.; Wei, Q. Ultrasensitive electrochemical immunoassay for BRCA1 using BMIM-BF4-coated SBA-15 as labels and functionalized graphene as enhancer. Biomaterials 2011, 32, 2117-2123. [CrossRef] [PubMed]

12. Feng, L.; Chen, Y.; Ren, J.; Qu, X. A graphene functionalized electrochemical aptasensor for selective label-free detection of cancer cells. Biomaterials 2011, 32, 2930-2937. [CrossRef] [PubMed]

13. Lee, T.J.; Park, S.; Bhang, S.H.; Yoon, J.K.; Jo, I.; Jeong, G.J.; Hong, B.H.; Kim, B.S. Graphene enhances the cardiomyogenic differentiation of human embryonic stem cells. Biochem. Biophys. Res. Commun. 2014, 452, 174-180. [CrossRef]

14. Lv, M.; Zhang, Y.; Liang, L.; Wei, M.; Hu, W.; Li, X.; Huang, Q. Effect of graphene oxide on undifferentiated and retinoic acid-differentiated SH-SY5Y cells line. Nanoscale 2012, 4, 3861-3866. [CrossRef] [PubMed]

15. Eva, G.; Maria, I.; Monika, S.; Claudio, S.; Sebastian, H.; Susan, J.K.; Valerie, K.; Georges, L.; Aravind, V.; Kiran, B. Graphene Oxide promotes embryonic stem cell differentiation to haematopoietic lineage. Sci. Rep. 2016, 6, 25917.

16. Newby, S.D.; Masi, T.; Griffin, C.D.; King, W.J.; Chipman, A.; Stephenson, S.; Anderson, D.E.; Biris, A.S.; Bourdo, S.E.; Dhar, M. Functionalized Graphene Nanoparticles Induce Human Mesenchymal Stem Cells to Express Distinct Extracellular Matrix Proteins Mediating Osteogenesis. Int. J. Nanomed. 2020, 15, 2501-2513. [CrossRef]

17. Lv, L.W.; Liu, Y.S.; Zhang, P.; Gu, M.; Bai, X.S.; Xiong, C.Y.; Zhou, Y.S. Transcriptomics and Functional Analysis of GrapheneGuided Osteogenic Differentiation of Mesenchymal Stem Cells. Chin. J. Dent. Res. 2018, 21, 101-111.

18. Luo, Y.; Shen, H.; Fang, Y.; Cao, Y.; Huang, J.; Zhang, M.; Dai, J.; Shi, X.; Zhang, Z. Enhanced Proliferation and Osteogenic Differentiation of Mesenchymal Stem Cells on Graphene Oxide-Incorporated Electrospun Poly (lactic-co-glycolic acid) Nanofibrous Mats. ACS Appl. Mater. Interfaces 2015, 7, 6331-6339. [CrossRef]

19. Hong, S.W.; Lee, J.H.; Kang, S.H.; Hwang, E.Y.; Hwang, Y.S.; Lee, M.H.; Han, D.W.; Park, J.C. Enhanced neural cell adhesion and neruite out-growth on graphene-based biomimetic substrates. BioMed. Res. Int. 2014, 2014, 212149. [CrossRef]

20. Yang, K.; Lee, J.; Lee, J.S.; Kim, D.; Chang, G.E.; Seo, J.; Cheong, E.; Lee, T.; Cho, S.W. Graphene oxide hierarchical patterns for the derivation of electrophysiologically functional neuron-like cells from human neural stem cells. ACS Appl. Mater. Interfaces 2016, 8 , 17763-17774. [CrossRef]

21. Yang, D.; Li, T.; Xu, M.; Gao, F.; Yang, J.; Yang, Z.; Le, W. Graphene oxide promotes the differentiation of mouse embryonic stem cells to dopamine neurons. Nanomedicine 2014, 9, 2445-2455. [CrossRef] [PubMed]

22. Jing, G.; Wang, Z.; Zhuang, X.; He, X.; Wu, H.; Wang, Q.; Cheng, L.; Liu, Z.; Wang, S.; Zhu, R. Suspended graphene oxide nanosheets maintain the self-renewal of mouse embryonic stem cells via down-regulating the expression of Vinculin. Biomaterials 2018, 171, 1-11. [CrossRef]

23. Hamidouche, Z.; Fromigué, O.; Ringe, J.; Häupl, T.; Marie, P.J. Crosstalks between integrin alpha 5 and IGF2/IGFBP2 signalling trigger human bone marrow-derived mesenchymal stromal osteogenic differentiation. BMC Cell Biol. 2010, 11, 44. [CrossRef] [PubMed]

24. Sipilä, K.; Haag, S.; Denessiouk, K.; Käpylä, J.; Peters, E.C.; Denesyuk, A.; Hansen, U.; Konttinen, Y.; Johnson, M.S.; Holmdahl, R.; et al. Citrullination of collagen II affects integrin-mediated cell adhesion in a receptor-specific manner. FASEB J. 2014, 28, 3758-3768. [CrossRef]

25. Tang, C.H.; Yang, R.S.; Huang, T.H.; Lu, D.Y.; Chuang, W.J.; Huang, T.F.; Fu, W.M. Ultrasound stimulates cyclooxygenase-2 expression and increases bone formation through integrin, focal adhesion kinase, phosphatidylinositol 3-kinase, and Akt pathway in osteoblasts. Mol. Pharmacol. 2006, 69, 2047-2057. [CrossRef]

26. Li, B.; Zhang, X.Y.; Yang, J.Z.; Zhang, Y.J.; Li, W.X.; Fan, C.H.; Huang, Q. Influence of polyethylene glycol coating on biodistribution and toxicity of nanoscale graphene oxide in mice after intravenous injection. Int. J. Nanomed. 2014, 9, 4697-4707. [CrossRef] [PubMed]

27. Kanakia, S.; Toussaint, J.D.; Mullick, C.S.; Tembulkar, T.; Lee, S.; Jiang, Y.P.; Lin, R.Z.; Shroyer, K.R.; Moore, W.; Sitharaman, B. Dose ranging, expanded acute toxicity and safety pharmacology studies for intravenously administered functionalized graphene nanoparticle formulations. Biomaterials 2014, 35, 7022-7031. [CrossRef]

28. Lee, H.; Dellatore, S.M.; Miller, W.M.; Messersmith, P.B. Mussel-inspired surface chemistry for multifunctional coatings. Science 2007, 318, 426-430. [CrossRef]

29. Cao, Y.; Shi, R.; Yang, H.; Zhang, J.; Ge, L.; Gao, R.; Fan, Z. Epiregulin promotes osteogenic differentiation and inhibits neurogenic trans-differentiation of adipose-derived mesenchymal stem cells via MAPKs pathway. Cell Biol. Int. 2020, 44, 1046-1058. [CrossRef] [PubMed] 
30. Yang, X.; Yang, Y.; Zhou, S.; Gong, X.; Dai, Q.; Zhang, P.; Jiang, L. Puerarin Stimulates Osteogenic Differentiation and Bone Formation Through the ERK1/2 and p38-MAPK Signaling Pathways. Curr. Mol. Med. 2018, 17, 488-496. [CrossRef] [PubMed]

31. Riddell, J.; Gazit, R.; Garrison, B.S.; Guo, G.; Saadatpour, A.; Mandal, P.K.; Ebina, W.; Volchkov, P.; Yuan, G.C.; Orkin, S.H.; et al. Reprogramming committed murine blood cells to induced hematopoietic stem cells with defined factors. Cell 2014, 157, 549-564. [CrossRef]

32. Sandler, V.M.; Lis, R.; Liu, Y.; Kedem, A.; James, D.; Elemento, O.; Butler, J.M.; Scandura, J.M.; Rafii, S. Reprogramming human endothelial cells to haematopoietic cells requires vascular induction. Nature 2014, 511, 312-318. [CrossRef]

33. Choi, J.S.; Mahadik, B.P.; Harley, B.A. Engineering the hematopoietic stem cell niche: Frontiers in biomaterial science. Biotechnol. J. 2015, 10, 1529-1545. [CrossRef]

34. Ireland, R.G.; Simmons, C.A. Human Pluripotent Stem Cell Mechanobiology: Manipulating the Biophysical Microenvironment for Regenerative Medicine and Tissue Engineering Applications. Stem Cells 2015, 33, 3187-3196. [CrossRef] [PubMed]

35. Han, L.; Sun, H.; Tang, P.; Li, P.; Xie, C.; Wang, M.; Wang, K.; Weng, J.; Tan, H.; Ren, F.; et al. Mussel-inspired graphene oxide nanosheet-enwrapped Ti scaffolds with drug-encapsulated gelatin microspheres for bone regeneration. Biomater. Sci. 2018, 6 , 538-549. [CrossRef]

36. Sun, M.; Chi, G.; Xu, J.; Tan, Y.; Xu, J.; Lv, S.; Xu, Z.; Xia, Y.; Li, L.; Li, Y. Extracellular matrix stiffness controls osteogenic differentiation of mesenchymal stem cells mediated by integrin alpha5. Stem Cell Res. Ther. 2018, 9, 52. [CrossRef] [PubMed]

37. Hamidouche, Z.; Fromigue, O.; Ringe, J.; Häupl, T.; Vaudin, P.; Pagès, J.C.; Srouji, S.; Livne, E.; Marie, P.J. Priming integrin alpha5 promotes human mesenchymal stromal cell osteoblast differentiation and osteogenesis. Proc. Natl. Acad. Sci. USA 2009, 106, 18587-18591. [CrossRef] [PubMed]

38. Saidak, Z.; Le Henaff, C.; Azzi, S.; Marty, C.; da Nascimento, S.; Sonnet, P.; Marie, P.J. Wnt/beta-catenin signaling mediates osteoblast differentiation triggered by peptide-induced alpha5beta1 integrin priming in mesenchymal skeletal cells. J. Biol. Chem. 2015, 290, 6903-6912. [CrossRef]

39. Moussa, F.M.; Hisijara, I.A.; Sondag, G.R.; Scott, E.M.; Frara, N.; Abdelmagid, S.M.; Safadi, F.F. Osteoactivin promotes osteoblast adhesion through HSPG and alphavbeta1 integrin. J. Cell. Biochem. 2014, 115, 1243-1253. [CrossRef]

40. Lee, H.M.; Seo, S.R.; Kim, J.; Kim, M.K.; Seo, H.; Kim, K.S.; Jang, Y.J.; Ryu, C.J. Expression dynamics of integrin alpha2, alpha3, and alphaV upon osteogenic differentiation of human mesenchymal stem cells. Stem Cell Res. Ther. 2020, 11, 210. [CrossRef]

41. Zheng, H.; Li, X.; Chen, Y.; Zhou, R.; Zhao, H.; Qian, C. Integrin subunits alphaV and beta3 promote the osteogenic differentiation of umbilical cord blood mesenchymal stem cells. Int. J. Clin. Exp. Pathol. 2018, 11, 2008-2016.

42. Olivares-Navarrete, R.; Rodil, S.E.; Hyzy, S.L.; Dunn, G.R.; Almaguer-Flores, A.; Schwartz, Z.; Boyan, B.D. Role of integrin subunits in mesenchymal stem cell differentiation and osteoblast maturation on graphitic carbon-coated microstructured surfaces. Biomaterials 2015, 51, 69-79. [CrossRef] [PubMed]

43. Zimmerman, D.; Jin, F.; Leboy, P.; Hardy, S.; Damsky, C. Impaired bone formation in transgenic mice resulting from altered integrin function in osteoblasts. Dev. Biol. 2000, 220, 2-15. [CrossRef] [PubMed]

44. Marie, P.J. Targeting integrins to promote bone formation and repair. Nat. Rev. Endocrinol. 2013, 9, 288-295. [CrossRef]

45. Brunner, M.; Jurdic, P.; Tuckerman, J.P.; Block, M.R.; Bouvard, D. New insights into adhesion signaling in bone formation. Int. Rev. Cell Mol. Biol. 2013, 305, 1-68. [PubMed]

46. Lu, M.; Zhuang, X.; Tang, K.; Wu, P.; Guo, X.; Yin, L.; Cao, H.; Zou, D. Intrinsic Surface Effects of Tantalum and Titanium on Integrin alpha5beta1/ERK1/2 Pathway-Mediated Osteogenic Differentiation in Rat Bone Mesenchymal Stromal Cells. Cell. Physiol. Biochem. 2018, 51, 589-609. [CrossRef] [PubMed]

47. Kim, H.Y.; Park, S.Y.; Choung, S.Y. Enhancing effects of myricetin on the osteogenic differentiation of human periodontal ligament stem cells via BMP-2/Smad and ERK/JNK/p38 mitogen-activated protein kinase signaling pathway. Eur. J. Pharmacol. 2018, 834, 84-91. [CrossRef]

48. Zhu, D.; Deng, X.; Han, X.F.; Sun, X.X.; Pan, T.W.; Zheng, L.P.; Liu, Y.Q. Wedelolactone Enhances Osteoblastogenesis through ERK- and JNK-mediated BMP2 Expression and Smad/1/5/8 Phosphorylation. Molecules 2018, 23, 561. [CrossRef]

49. Liang, L.; Zhou, W.; Yang, N.; Yu, J.; Liu, H. ET-1 Promotes Differentiation of Periodontal Ligament Stem Cells into Osteoblasts through ETR, MAPK, and Wnt/ $\beta$-Catenin Signaling Pathways under Inflammatory Microenvironment. Mediat. Inflamm. 2016, 2016, 8467849. [CrossRef]

50. Horvath, L.; Magrez, A.; Burghard, M.; Kern, K.; Forro, L.; Schwaller, B. Evaluation of the toxicity of graphene derivatives on cells of the lung luminal surface. Carbon 2013, 64, 45-60. [CrossRef]

51. Bidram, E.; Sulistio, A.; Cho, H.J.; Amini, A.; Harris, T.; Zarrabi, A.; Qiao, G.; Stewart, A.; Dunstan, D.E. Targeted Graphene Oxide Networks: Cytotoxicity and Synergy with Anticancer Agents. ACS Appl. Mater. Interfaces 2018, 10, 43523-43532. [CrossRef]

52. Dudek, I.; Skoda, M.; Jarosz, A.; Szukiewicz, D. The Molecular Influence of Graphene and Graphene Oxide on the Immune System under In Vitro and In Vivo Conditions. Arch. Immunol. Ther. Exp. 2016, 64, 195-215. [CrossRef] [PubMed]

53. Zhu, J.; Li, B.; Xu, M.; Liu, R.; Xia, T.; Zhang, Z.; Xu, Y.; Liu, S. Graphene Oxide Promotes Cancer Metastasis through Associating with Plasma Membrane to Promote TGF- $\beta$ Signaling-Dependent Epithelial-Mesenchymal Transition. ACS Nano 2020, 14, 818-827. [CrossRef]

54. Wang, M.; Li, J.; Ye, Y.; He, S.; Song, J. SHED-derived conditioned exosomes enhance the osteogenic differentiation of PDLSCs via Wnt and BMP signaling in vitro. Differentiation 2020, 111, 1-11. [CrossRef] [PubMed] 
55. Wang, J.; Wang, M.; Chen, F.; Wei, Y.; Chen, X.; Zhou, Y.; Yang, X.; Zhu, X.; Tu, C.; Zhang, X. Nano-Hydroxyapatite Coating Promotes Porous Calcium Phosphate Ceramic-Induced Osteogenesis Via BMP/Smad Signaling Pathway. Int. J. Nanomed. 2019, 14, 7987-8000. [CrossRef]

56. Chen, X.; Zhang, S.; Chen, X.; Hu, Y.; Wu, J.; Chen, S.; Chang, J.; Wang, G.; Gao, Y. Emodin promotes the osteogenesis of MC3T3-E1 cells via BMP-9/Smad pathway and exerts a preventive effect in ovariectomized rats. Acta Biochim. Biophys. Sin. 2017, 49, 867-878. [CrossRef]

57. Yang, J.H.; Kim, S.C.; Kim, K.M.; Jang, C.H.; Cho, S.S.; Kim, S.J.; Ku, S.K.; Cho, I.J.; Ki, S.H. Isorhamnetin Attenuates Liver Fibrosis by Inhibiting TGF- $\beta$ /Smad Signaling and Relieving Oxidative Stress. Eur. J. Pharmacol. 2016, 783, 92-102. [CrossRef] [PubMed]

58. Yoon, B.S.; Ovchinnikov, D.A.; Yoshii, I.; Mishina, Y.; Behringer, R.R.; Lyons, K.M. Bmpr1a and Bmpr1b have overlapping functions and are essential for chondrogenesis in vivo. Proc. Natl. Acad. Sci. USA 2005, 102, 5062-5067. [CrossRef]

59. Sánchez-Duffhues, G.; Hiepen, C.; Knaus, P.; Ten Dijke, P. Bone morphogenetic protein signaling in bone homeostasis. Bone 2015, 80, 43-59. [CrossRef]

60. Wang, H.; Chen, F.; Li, J.; Wang, Y.; Jiang, C.; Wang, Y.; Zhang, M.; Xu, J. Vaspin antagonizes high fat-induced bone loss in rats and promotes osteoblastic differentiation in primary rat osteoblasts through Smad-Runx2 signaling pathway. Nutr. Metab. 2020, 17, 9. [CrossRef]

61. Ding, S.; Zhang, J.; Tian, Y.; Huang, B.; Yuan, Y.; Liu, C. Magnesium modification up-regulates the bioactivity of bone morphogenetic protein-2 upon calcium phosphate cement via enhanced BMP receptor recognition and Smad signaling pathway. Colloids Surf. B Biointerfaces 2016, 145, 140-151. [CrossRef] [PubMed]

62. An, S.Y.; Lee, H.J.; Lee, S.C.; Heo, J.S. Supplement of nitric oxide through calcium carbonate-based nanoparticles contributes osteogenic differentiation of mouse embryonic stem cells. Tissue Cell 2020, 66, 101390. [CrossRef] [PubMed]

63. Lee, J.S.; Lee, J.C.; Heo, J.S. Polydopamine-assisted BMP-2 immobilization on titanium surface enhances the osteogenic potential of periodontal ligament stem cells via integrin-mediated cell-matrix adhesion. J. Cell Commun. Signal. 2018, 12, 661-672. [CrossRef] [PubMed]

64. Lee, J.S.; Kim, E.; Han, S.; Kang, K.L.; Heo, J.S. Evaluating the oxysterol combination of 22(S)-hydroxycholesterol and 20(S)hydroxycholesterol in periodontal regeneration using periodontal ligament stem cells and alveolar bone healing models. Stem Cell Res. Ther. 2017, 8, 276. [CrossRef] [PubMed] 